\title{
Research on Art Design Application of Modern Ceramic Techniques
}

\author{
Keke Tao ${ }^{1}$ \\ ${ }^{1}$ Culture and Art Management, Honam University, South Korea \\ Correspondence: Keke Tao, Culture and Art Management, Honam University, South Korea.
}

Received: November 10, 2021

Accepted: December 8, 2021

Online Published: December 13, 2021

doi:10.20849/ajsss.v6i5.962

URL: https://doi.org/10.20849/ajsss.v6i5.962

\begin{abstract}
In the process of modern art design, ceramic techniques are widely used and can fully show modern ceramic art. In this paper, the application of ceramic techniques was deeply explored. Firstly, the basic characteristics of modern ceramic techniques and art were briefly described, and then the application status of modern ceramic techniques art design was analyzed. Finally, the main application measures of ceramic techniques were discussed emphatically, including plane design, indoor design, product design, decoration design, so as to show the innovative development of modern ceramic techniques and provide some reference for the relevant personnel.
\end{abstract}

Keywords: ceramic techniques, art design, graphic design

\section{Introduction}

Ceramic art has different characteristics in expression and shows diversified art in ceramic techniques, which has strong implication and decoration. In the process of modern social development, ceramic techniques are continuously fully used and applied in various industries. The practical advantages of ceramic techniques are continuously exerted, the artistic design content is improved, and the concept of modernization is gradually adapted. At the same time, with the exploration and development of ceramic techniques, in the field of artistic design, the application of ceramic techniques has been strengthened, its good results have been focused, and more artistic effects have been added to the relevant design.

\section{Basic Characteristics of Modern Ceramic Techniques and Art}

Ceramics prevailed in the Tang Dynasty, and then people continue to explore and improve it. It is integrated into the corresponding artistic design to fully show China's traditional culture and historical civilization with unique artistic characteristics. Modern ceramic techniques are quite different from traditional techniques. The artistic characteristics of modern ceramic technology are mainly manifested in emotions. Artists usually integrate their emotions into artistic works and fully express their concepts and emotions. In the traditional ceramic art, it is usually to show the social situation. In the traditional period, as one of the main objects in life, the practicability of ceramics is the main pursuing purpose. On this basis, people pay attention to the structural aesthetics of objects and so on. Therefore, in traditional ceramic art, the expression of emotional concepts is usually more obscure and fails to appear directly, and is often naturally revealed in ceramic art production. In modern ceramic art, emotion is usually directly expressed in art works, which allows people to fully feel the corresponding resonance through their understanding of art design. At the same time, in the artistic expression of modern ceramic techniques, more attention is paid to social experience and people's consciousness, and attention is paid to cultural characteristics and experience, etc., moreover, the overall form of expression is more rich. Moreover, in modern ceramic techniques, there are relatively many modes of performance, such as virtual reality, ironic banter, and reinterpretation of tradition. In the process of its application, the effective combination of aesthetics and practicality is continuously highlighted, and the expression of culture is fully demonstrated. In modern ceramic techniques, it is gradually studied in detail, its application is strengthened, its application range is expanded, and a good reference basis is provided for related art designs (Quan, Y., 2020). On the basis of traditional ceramic techniques, it is deeply explored and continuously applied in various art designs to improve the application efficiency of modern ceramic techniques, promote the comprehensive promotion of ceramic technology, and fully show the cultural value of ceramic art.

\section{Application Status of Modern Ceramic Techniques and Art Design}

In the development process of today's society in China, science and technology have been improved as a whole, and the development of various fields has gradually attached importance to innovative concepts, gradually 
applied them to various industries, and promoted the development of various industries to enter a brand-new stage. In the art field, with the popularization of innovative ideas, new design ideas and design methods gradually appear, therefore, the content of artistic works are enriched, the diversity of artistic design are increased, the progress of artistic innovation and artistic design are effectively promoted with a good development trend, which provide a broad development space for it. Therefore, most designers continue to fully apply unique ceramic elements to provide designers with the corresponding inspiration, so as to fully show our national culture. Ceramic art is an important part of Chinese traditional culture, which effectively shows the spirit of the times and gradually promotes the overall development of ceramic techniques in the process of its application. In modern society, it can be integrated into various artistic designs to achieve good design results and show great artistic value, which can effectively inherit the traditional culture and recognize the important role of cultural development. Therefore, designers continue to promote modern ceramic techniques as a whole and strengthen the use of traditional culture, which can effectively promote the good development of the field of artistic design.

At the same time, under the current social and economic development, the traditional art in China suffers from different degrees of damage, resulting in the gradual reduction of traditional art works and the inability to effectively protect the relevant design contents, so the art design works are often affected by external factors for a long time, resulting in greater damage. At the same time, in the process of art design, some designers fail to recognize the value of traditional culture, in the process of design, blindly pay attention to innovation, and do not improve on the basis of traditional culture. In its art design works, the content of traditional culture cannot be displayed, which leads to the failure of effective inheritance of traditional culture and affects the development of national culture. Moreover, during design process, some designers integrate a large number of western design concepts with the ignorance of traditional culture in China and fail to attract the attention of designers with lackness of awareness of traditional culture, so designers use ceramic techniques with relatively low efficiency. In its design works, it fails to effectively integrate the corresponding folk culture and lacks unique folk customs, which leads to the difficulty in achieving a good inheritance effect of traditional national culture. Therefore, designers should pay full attention to it by intensifying the application of modern ceramic techniques in the process of art design, gradually applying them to various fields, improving the design level of various fields, fully carrying forward the traditional culture of China, and effectively promoting the rapid development of the field of art design.

\section{Main Application Measures of Ceramic Techniques Art Design}

\subsection{Application of Graphic Design}

In the graphic design, the packaging design is mainly represented. In this design, it integrates the brand-new design concept, effectively improves the hierarchical sense of packaging, and also has a greater impact on the economy of packaged commodities. Therefore, the designers continuously attach importance to the artistic nature of packaging design and clarify the specific design direction (Zou, X., Zhang, Y., \& Zhao, S.-X., 2020). In the actual design process, designers are required to: deeply analyze the packaged commodities, master the actual advantages of commodities, and apply corresponding cultural content in combination with the current cultural development trend in China, gradually strengthen the application of ceramic elements, apply modern ceramic techniques to the packaging design content, improve the packaging design concept, effectively enrich the packaging design content. It can effectively achieve a good design effect. At the same time, under the packaging design, the personnel continues to investigate the current design trend, so as to continuously reach a deep understanding of modern ceramic techniques, fully pursue the national design concept and carry out a comprehensive thinking on traditional culture, finally, to strengthen the study of traditional art. Exploring and innovating on the basis of traditional culture and art can effectively enhance the packaging level. The use of ceramic art can fully provide good results for designers to show a unique form of art. Moreover, designers should carry out comprehensive innovation from each link and integrate modern ceramic techniques into each detail design to show different style characteristics, and further embody strong uniqueness in various aspects such as packaging shape, material and color. At present, designers combine packaging design with artistic elements, and innovate packaging forms to effectively improve the quality of packaging design and enhance the aesthetic effect of packaging. At the same time, under the application of modern ceramic techniques, it can also effectively enrich the connotation of packaging design and appropriately increase the corresponding cultural content, which can fully show the design sense of packaging and gradually highlight the function of ceramic art, as well as play the main role of ceramic techniques and show the essence of traditional art design. Promoting packaging design generates a good aesthetic effect which can attract a large number of consumers, so as to promote the good development of commodity sales by improving the sales volume of products. It can fully embody the advantages 
of packaging design and promote the wide range of promotion of modern ceramic techniques.

\subsection{Indoor Design and Application}

At present, with the rapid development of China's economy, people's living standards have been gradually improved. They constantly pursue high-quality life and pay full attention to indoor design. Good design can create a warm and comfortable environment for people. Therefore, indoor designers had strengthened the innovation of design methods by adopting reasonable embodiment techniques and applying modern ceramic elements. Under different performance ways, designers increase the vitality of indoor space, and fully beautify people's work and living environment through the study of indoor design, so as to bring good enjoyment for people and enhance people's sense of experience. For this reason, in the indoor design process, the personnel needs to carry out a detailed analysis around the ceramic pattern. In general, ceramics contain relatively many patterns, such as phoenix-pattern, dragon-pattern, etc. Through the understanding of various patterns, designers continue to carry out in-depth innovation on them, fully extract representative factors, and reasonably integrate them into indoor design, which can effectively add more cultural connotation to indoor space (Ma, H.-Y., 2019). At the same time, in the design process, the art form of ceramics is also relatively more presented in the vase, porcelain plate, sculpture and other ways for the effective embellishment of indoor, which can fully increase the aesthetic sense of indoor design. Generally, in the indoor design process, designers take different ceramic techniques according to different indoor uses. For example, in public spaces, designers usually use porcelain painting, that is, porcelain as a paintpaper for creation, which allows people to fully experience the feeling of nature and make people accept strong artistic edification. Moreover, in the application process of modern ceramic techniques, daily porcelain is continuously studied in detail, and reasonable innovation is carried out to gradually meet people's aesthetic requirements. In indoor design, designers can adopt ceramic art in tableware, tea sets and lamps to fully show the practicability of modern ceramics. It provides good design results and effectively improves the indoor environment. Promoting people to get a comprehensive relaxation in this environment is of great help to alleviate people's pressure. It shows the application advantages of modern ceramic techniques in art design, promotes the long-term development of the field of art design. Furthermore, it actively inherits the traditional national culture of China, creates a good atmosphere for people, and improves the overall level of indoor design.

\subsection{Product Design and Application}

At present, there is a serious phenomenon of plagiarism in the product design in China by frequently quoting and transforming the western design modern with the attention of making a greater impact on the product. Moreover, in the process of product design, there is a lack of national characteristics, which fails to show the advantages of personalized product, so that the product design content is difficult to meet the development needs of the current era as well as people's aesthetic standards. It leads to the gradual decline of product sales and the reduction of sales income of products, and brings greater losses to the economic development of related enterprises. Therefore, designers continue to strengthen the attention to product design by fully integrating traditional cultural elements in China, increasing national cultural content and continuously using modern ceramic techniques. They reasonably improve the current product design concept and comprehensively combine ceramic elements with product design. By displaying in different forms, it can effectively improve the product design level, bring brand-new visual experience to people, fully attract consumers, so as to drive product sales and increase the economic benefits of related enterprises. At the same time, in the process of product design, the personnel use ceramic techniques to optimize the design content and carry out analysis according to the overall structure of the product, and further appropriately add the corresponding cultural content around the ceramic elements to improve the overall design plan, strengthen the innovation of product design, promote the good development of traditional cultural art in China, so that the product design gradually meets people's aesthetic requirements, conforms to the development trend of modernization, and promotes the long-term development of related products. For example, in the design process of lamp products, the personnel also first comprehensively explore the purpose of lamps and the environment in which they are located, integrate the corresponding ceramic techniques according to the actual situation of lamps, and fully display the form of diversified ceramic elements. At the same time, in the process of lamp design, the designer can adopt the corresponding ceramic style and structure to improve the design content and fully combine the lamp with the ceramic, which can effectively obtain good design results. Therefore, in the product design, the application of modern ceramic techniques can provide great help for the design and gradually increase the experience of designers. This can make it adopt diversified national culture in product design, so as to strengthen the inheritance of traditional culture and show the application advantages of ceramic elements. In addition, it can also enhance the uniqueness of products, continuously promote the development of related products to modernization and nationalization, effectively 
expand the design style of products, so as to achieve high-quality design results.

\subsection{Application of Decorative Design}

In the decorative design of China, it is widely used in modern ceramic techniques. Considering the long history of ceramic art development and strong traditional culture, it usually contains more techniques and forms in the process of ceramic fabrication and plays an important role in decorative design. To this end, designers should fully integrate the decorative design with ceramic techniques. This leads to a brand-new decorative style. In the process of decorative design, the personnel can explore from the materials, colors, patterns and other aspects and use the corresponding decorative form to achieve a good aesthetic effect, and finally enhance the artistic performance of decorative design (Ning, Q.-Z., 2019). At the same time, in the actual decoration design process, designers need to clarify the purpose of the space and the specific theme style and then conduct design according to people's own requirements, in which continuous reasonable matching of various elements is required to strengthen the coordination and unity of the design. Moreover, in the decoration design, designers are required to gradually collect the corresponding design materials together with reasonable analysis of design elements and spatial style as well strengthening of the relationship between materials and elements, so as to show a good design artistic conception. In general, decorative design and indoor design has a greater correlation. During designing, designers should fully consider the overall design style of the room. Therefore, the corresponding decorative design is used for embellishment, such as vases, furniture, carpets, etc., which is fully integrated into ceramic techniques to improve the design of traditional patterns. In addition, in decorative design, we should also learn from other artistic elements by adopting brand-new design ideas, so as to promote the overall development of artistic design and effectively show the progress of society. Adding national characteristics to various design contents can fully increase people's attention to design and meet people's demand standards. Therefore, under the application of modern ceramic techniques, it can effectively drive the overall development of various art design fields, and to further create more benefits for China's economy and improve China's economic development level, and finally, to realize the overall goal of art design.

Conclusion: In summary, modern ceramic techniques are of great significance in artistic design and contain many cultural characteristics in ceramic techniques, which can fully demonstrate the traditional national culture of China. At present, under the economic development of China, more and more attention are payed to the cultural inheritance and modern ceramic techniques are applied to art design, which can effectively respond to the basic policies of China and meet the development requirements of modernization. Therefore, various fields continue to link ceramic techniques with art design to strengthen art design innovation, highlight national consciousness, carry forward traditional culture, and further promote the sustainable and long-term development of art design.

\section{References}

Ma, H.-Y. (2019). Study on the Comprehensive Mode of Contemporary Ceramic Art - Glazing Decorative Techniques with High Temperature Color Glaze. Ceramic Research, 34(6), 3.

Ning, Q.-Z. (2019). Excellent Trees, Loyal Heart, Varied Customs - a Variety of Porcelain Production Techniques to Innovate Contemporary Porcelain. Tai Sheng, (16), 4.

Quan, Y. (2020). Application of Comprehensive Decorative Techniques in the Design of Ceramic Mural Paintings - The exterior wall of the Ceramic Are Studio of Guilin Tourism College. Tiangong, (5), 2.

Zou, X., Zhang, Y., \& Zhao, S.-X. (2020). Study on the Presentation of Modern Ceramics in the Design of Colorful Porcelain under Liling Glazing. Journal of Ceramics, 41(3), 5.

\section{Copyrights}

Copyright for this article is retained by the author(s), with first publication rights granted to the journal.

This is an open-access article distributed under the terms and conditions of the Creative Commons Attribution license (http://creativecommons.org/licenses/by/4.0/). 